\title{
Antimicrobial, Nutritional and Phytochemical Properties of Monodora Myristica Seeds
}

\author{
Stephen A. Enabulele ${ }^{1}$ Fred O. J. Oboh ${ }^{1}$ and Eseosa O. Uwadiae ${ }^{1}$ \\ Department of Basic Sciences, Benson Idahosa University, Benin City, Nigeria
}

\begin{abstract}
Seeds of Monodora myristica was investigated for its antimicrobial, nutritional and phytochemical properties. Results of the study, shows that the aqueous and ethanolic extracts of the seeds, were active against both gram negative and gram positive organisms used. Important bioactive constituents found to be present in the extracts were alkaloids, anthraquinones, cardiac glycosides, flavonoids, saponins, and phenolic compounds. Yield extracts of the powdered seeds, was for water $7.94 \%$ and ethanol $12.5 \%$, indicating that ethanol was the better of the two solvents used. Results of the antibacterial activity of the extracts reveal that the ethanolic extracts at different concentrations were more active against the test organisms namely Staphylococcus aureus, Klebsiella pneumonia, Escherichia coli and Salmonella typhi than the aqueous extracts. The minimum inhibitory concentration (MIC) values for the aqueous extract ranged between 2.5 and $3.0 \mathrm{mg} / \mathrm{ml}$ while that for ethanolic extract was between 2.5 and $3.5 \mathrm{mg} / \mathrm{ml}$. The minimum bacterial concentration (MBC) values for aqueous extract ranged between 3.0 and $3.5 \mathrm{mg} / \mathrm{ml}$ while that for ethanolic extract ranged between 3.5 and 4.0 $\mathrm{mg} / \mathrm{ml}$. Nutritionally result from the study justifies the use of the seed as both a spice and food component by locals. The seed was particularly found to be very rich in potassium and magnesium. There is therefore the need for further studies on the active components of the seeds of Monodora myristica so as to maximize its medicinal and nutritional potential.
\end{abstract}

Key Words: Antimicrobial, Monodora myristica, Nutritional, Phytochemical, Spices

\section{Introduction}

Borget (1993),[1] defined spices as vegetable substances of indigenous or exotic origin which is aromatic or has a hot piquant taste, used to enhance the flavor of foods or to add to foods the stimulating ingredients contained in them. Most cultures of the world have used spices and herbs for thousands of centuries as part of their daily foods to enhance flavor and aroma. Although most spices are added to food recipes primarily to function as seasoning rather than for its nutritional benefits, their nutritional and phytochemical potential however has not been overlooked. Early cultures have been known to recognize the value of using spices and herbs in preserving foods and for their medicinal values. Scientific evidences abound of the antimicrobial properties of most spices, herbs and their components ([2], [3], [4]). Basically when used for medicinal purpose to enhance well being, their values can be observed from the phytochemical components they possess. These phytochemicals, which have been observed, to be present in small quantities as secondary metabolites include among others, alkaloids, steroids, tannins, flavonoids, and phenolic compounds [5]. Also as preservative, essential oils extracted from spices and herbs have been generally recognized as containing active antimicrobial compounds such as allicin, allyl isothocyanate, eugenol, carvacrol and thymol that can inhibit the growth of both gram positive and gram negative bacteria [2], as well as prevent mold growth in addition to adding flavor and aroma to baked products ([6], [7]). Foods containing these phytochemicals not only can provide our diet with certain antioxidant vitamins like vitamin C, vitamin E and pro-vitamin A, but can also provide a complex mixture of other natural substances with antioxidant capacity [8]. Extracts from spices have also been shown to possess very good antioxidant properties beneficial in the prevention of some off-flavor development, in snack foods and meat products [9].

The plant kingdom represents an enormous reservoir of biologically active compounds with various chemical structures. With many of the indigenous plants being used as spices and food, knowledge of their chemical constituent becomes very important, not only for their nutritive value, but also for discovering new sources of economic materials and drugs for the treatment of recalcitrant infectious agents. Additionally, knowledge of the chemical constituents of these plants used as spices and herbs helps in the discovery of the true relevance of folkloric medicines [10]. African nutmeg (Monodora myristica), which belong to the Ananacea family is a berry with many seeds that grows well in the evergreen forests of West Africa [11] and is very prevalent in the Southern part of Nigeria where it is variously known as Iwor amongst the Itsekiris; Ikposa (Bini); Ehiri (Ibo); and Ariwo (Yoruba). It is observed that almost every part of the tree has both economic and medicinal importance. However; the most economically important parts are the seeds which are embedded in the white sweet-smelling pulp of the fruit. When grounded to powder, the seed (Plate 1) is used as spice to 
prepare pepper soup and also used as stimulant to relieve constipation and to control passive uterine hemorrhage in women immediately after child birth [12].

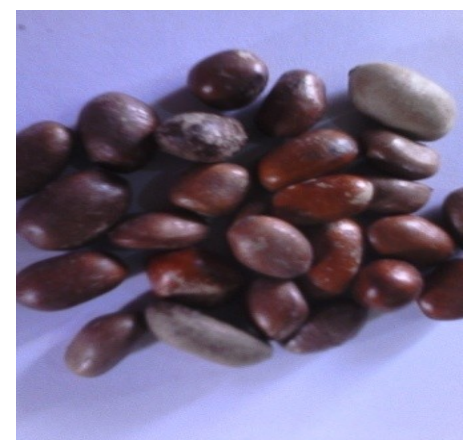

Plate 1: Seeds of Monodora myristica

Monodora myristica is used widely in Nigeria for culinary purposes, and sometimes traditionally for its medicinal properties, not much is however documented of its antimicrobial and nutritional properties. Most documented report on the seed are mostly on the antioxidant properties of essential oils ([13], [14]). This study was therefore designed to investigate the antimicrobial, nutritional and phytochemical properties of the crude extract of the seeds of Monodora myristica. Result of the study is expected to augment available data on the nutritional and medicinal value of the plant seed.

\section{Source of Monodora myristica seeds}

\section{Materials And Methods}

Seeds of Monodora myristica were purchased from "Yanga" sub section of Oba market, Benin City, Nigeria and the scientific name authenticated by Professor J. E. Ehiagbonare of the Department of Biological Sciences, Igbinedion University, Okada.

\section{Preparation of Sample}

The seeds were sun dried in the open for five days, after which they were shelled and milled into powder with a dry sterile Panasonic blender model MX-J120P. The powdered seeds were then sieved through a $2.0 \mathrm{~mm}$ filter and subsequently stored in an air tight sterile container until it was used.

\section{Seed extract preparation}

The seed extract was obtained by using the method previously described by [15]. $100 \mathrm{~g}$ of the powdered sample was soaked in $400 \mathrm{ml}$ of solvent in a sterile conical flask. It was then plugged, wrapped with aluminum foil and shaken vigorously. The mixture was left to stand for 24 hours in a shaking water bath maintained at $40^{\circ} \mathrm{C}$. The mixture was then filtered using a clean muslin cloth and Whatman No. 1 filter paper. Thereafter the filtrate was evaporated to dryness by means of a rotary evaporator attached to a vacuum pump. The percentage yield of each of the crude extract was determined for each solvent and estimated as dry weight (extract) / dry sample weight $\mathrm{x}$ 100. The extracts were stored in refrigerator until needed for further analysis.

\section{Microorganisms}

The species of microorganisms used in the investigation were Staphylococcus aureus,

Klebsiella pneumonia, Escherichia coli and Salmonella typhi. The organisms were clinical isolates obtained from the microbiology laboratory of the University of Benin Teaching Hospital Benin City. The cultures of bacteria were maintained on nutrient agar slants at $4^{\mathrm{O}} \mathrm{C}$, re-identified by biochemical tests according to methods outlined by [16] and [17].

\section{Phytochemical screening of seed extract}

Phytochemical screening of the seed extracts for Alkaloids, Anthraquinones, Cardiac glycosides, Flavonoids, Phenolic compounds, Saponins, Steroids, Tannins and Tapenoids were carried out using the methods earlier used and highlighted by [18].

\section{Determination of Minimum Inhibitory Concentration (MIC) and Minimum Bacterial Concentration (MBC)}

The MIC was determined using the tube dilution method. Standardized suspensions of the test organism was inoculated into a series of sterile tubes of nutrient broth containing different concentrations of leaf extracts and incubated at $37^{\circ} \mathrm{C}$ for 24 hours. The MICs were read as the least concentration that inhibited the 
growth of the test organisms [19]. The MBCs were determined by first selecting tubes that showed no growth during MIC determination; a loopful from each tube was sub-cultured onto extract free agar plates, incubated for another 24 hours at $37^{\circ} \mathrm{C}$. The minimum bacterial concentration (MBC) was considered as the lowest concentration that could not produce a single bacterial colony [19].

\section{Nutritional and Mineral content Estimation}

The recommended methods of the Association of Official Analytical Chemists [20], earlier used and enumerated by [18] were used for the determination of the nutritional and mineral content.

\section{Results And Discussion}

Results of the investigation are presented in tables 1 to 6 . The results showed the presence of important Phytochemical and nutritional constituents. It also showed significant antimicrobial activity against the organisms tested.

Percentage yield of the aqueous and ethanolic extracts of the powdered seeds of Monodora myristica (table 1), is for water $7.94 \%$ and ethanol $12.50 \%$. This yield is higher than that obtained by [18], for another plant seed Perinary excelsa who recorded $8.45 \%$ and $6.32 \%$ for water and ethanol respectively. El-Mahmood et al., (2008)[21] observed that factors like the age and type of plant material, and polarity of the solvent used could affect extract yield. Ethanol in this study, seem to be the better of the two solvents used as the yield was almost double that for water as solvent.

Phytochemical screening of the crude extracts of Monodora myristica, seeds revealed the presence of some important bioactive components as shown in table 2. It contains very high amounts of phenolic compounds and tapenoids in both the aqueous and ethanolic extracts, while alkaloids, anthraquinones, and cardiac glycosides were present in moderately high amounts in the aqueous extracts. Alkaloids and flavonoids were also present in moderately high amounts in the ethanolic extracts. Saponins and tannins were present in trace amounts in both the aqueous and ethanolic extracts. Steroids were not detected in either of the extracts. Basically the bioactive compounds found in this study have been severally proven to be active against human pathogens ([15], [22], [18]). Aside from their potential antimicrobial activity, bioactive phytochemical compounds found in this study such as alkaloids are known antimalarial agents, analgesics and can act as stimulants. Glycoside moieties such as saponins, anthraquinones, and cardiac glycosides can inhibit tumor growth, act as an antiparasitic agent and can be used as an antidepressant [23].

Table 1: Percentage yield of the crude extracts Monodora myristica seeds

\begin{tabular}{llll}
\hline Extraction Solvent & Seed powder $(\mathrm{g})$ & Extracted Seed Powder $(\mathrm{g})$ & Yield $(\%)$ \\
\hline Aqueous & 100 & 7.94 & 7.94 \\
Ethanol & 100 & 12.5 & 12.5 \\
\hline
\end{tabular}

Table 2: Phytochemical Constituents of Crude extracts of Monodora myristica seeds

\begin{tabular}{lcc}
\hline & \multicolumn{3}{c}{ Solvents $(\mathrm{mg} / \mathrm{ml})$} \\
\cline { 2 - 3 } Constituents & Aqueous & Ethanol \\
\hline Alkaloids & ++ & ++ \\
Anthraquinones & ++ & + \\
Cardiac glycosides & ++ & +++ \\
Flavonoids & + & ++ \\
Phenolic compounds & +++ & +++ \\
Saponins & + & + \\
Steroids & - & - \\
Tannins & + & + \\
Tapenoids & +++ & +++ \\
\hline
\end{tabular}

Key: $+++=$ Present in high amount; $++=$ Present in moderately high amount

$+=$ Present in trace amount; - = Absent

Results of the nutritional analysis of the seeds of Monodora myristica shown in table 3 indicate that the seed has a balanced nutritional composition with the carbohydrate content amounting to about $28.4 \%$, followed by lipids and fibre with $22.7 \%$ and $19.1 \%$ respectively. Ash content was the least with $2.6 \%$. Nutritionally, plant foods that provide less than $12 \%$ of its calorific value from protein are normally not considered good source of protein in diet. Seeds of Monodora myristica with a protein content of $9.6 \%$ which although is a bit close to the required $12 \%$ cannot be said to be an important source of protein in the diet. It could however be a good source of important enzymes which is the form on which most proteins in spices are found [24]. Even though the seeds are used as spices, the carbohydrate and lipid contents are quite appreciable and could be regarded as good sources of carbohydrate and especially essential oils for the body. The anti-hypertensive effect of essential oils derived from seeds of Monodora myristica have earlier been studied by [25]. Their investigation which shows 
the oil to contain mainly monoterpenoids, indicate that the essential oils have an anti-hypertensive activity. Essential oils derived from the cotyledons of such seeds have been shown to have high saponification value, low iodine and acid values and could be used for their medicinal and antioxidant properties [26].

Result of the mineral analysis of the seeds is as shown in table 4 . The metabolic functions of minerals for life are well documented in literature ([27], [28]). Potassium and sodium influences osmotic pressure and contribute to normal $\mathrm{pH}$ equilibrium, magnesium is an activator in enzyme systems which maintain electrical potentials in nerves, calcium is an important constituents of body fluids and bone formation in conjunction with phosphorus, while zinc forms metallo-proteins and enzyme complexes which cannot be dissociated without loss of activity.

The result of the mineral analysis indicate that potassium constitute 800.20 , iron 20.42 , magnesium 913.80, zinc 1.26 , sodium 15.49 and calcium 421.84 all in $\mathrm{mg} / 100 \mathrm{ml}$. Recommended daily allowance (RDA) values are added for comparison. The seed appears to be very rich in potassium and magnesium with the potassium value exceeding by far the RDA values. Although the contribution of the seed to the total dietary requirement for other minerals apart from potassium and magnesium seem to be minor, it is important to note that the nutritional value of spices depends not only on the concentration of nutrients in a particular food produce, but also on the amount consumed in the daily diet. Since spices are usually eaten in combination with other dietary components, some of which may be better sources of minerals under consideration, this spice seed could be of value in supplementing the minerals available from these other sources.

Table 3: Proximate composition of Monodora myristica seeds

\begin{tabular}{lc}
\hline Nutritional Properties & Content $(\mathrm{g} / 100 \mathrm{~g})$ \\
\hline Moisture & 11.2 \\
Lipids & 22.7 \\
Protein & 9.6 \\
Carbohydrate & 28.4 \\
Fibre & 19.1 \\
Ash & 2.6 \\
\hline
\end{tabular}

Table 4: Mineral Content of Monodora myristica seeds and recommended daily allowance in $\mathrm{mg} / 100 \mathrm{ml}$

\begin{tabular}{lll}
\hline Mineral & Content $(\mathrm{mg} / 100 \mathrm{ml})^{\mathrm{A}}$ & $\mathrm{RDA}^{\mathrm{B}}(\%$ of RDA $)$ \\
\hline Potassium & 800.2 & $18(4445.6)$ \\
Iron & 20.42 & $400(5.11)$ \\
Magnesium & 913.8 & $1000(91.4)$ \\
Zinc & 1.26 & $15(8.4)$ \\
Sodium & 15.49 & $2300(6.73)$ \\
Calcium & 421.84 & $3500(12.05)$ \\
\hline
\end{tabular}

$\mathrm{A}=$ This Study; $\mathrm{B}=$ Recommended daily allowance (RDA) [29]

Generally the effectiveness of any antimicrobial compound depends on the ability of the antimicrobial to inhibit or stop the growth of any microorganism in the body system they infect. Because of the high genetic variability of microorganisms, they seem to however develop the ability to rapidly evade the action of antimicrobials by becoming resistant to them. It becomes necessary therefore to consistently look for newer means of eliminating microbial threat of causing infections. Results of the antibacterial activity of the seed extracts of Monodora myristica against four clinical isolates namely Staphylococcus aureus, Escherichia coli, Klebsiella pneumonia and Salmonella typhi at different concentration are presented in table 5. The result indicates that the extracts are effective though at varying degrees, to all the test organisms. This result is in agreement with that of [18] and [30], who both reported that susceptibility of bacteria to plant extracts on the basis of zones of inhibition varies according to strains and species.

It is observed that at various concentrations, the ethanolic extracts were more active against the test organisms than the aqueous extracts. Various researchers have reported alcohol based extracts to be more effective than water based extracts ([31], [23], [32]) while others have also reported contrary results ([33], [15]). Traditionally, plant parts are soaked in water and alcohol based solvents for days before they are administered. The result from this study therefore, lends credence to the folkloric use of these solvents in traditional medicine as extracts from both solvents were found to be highly effective against all the test organisms.

Comparison of the percentages of effectiveness of the various extracts at different concentrations with the control antibiotic indicates that at the concentrations they were used, most of the extract were more than half as effective as the control even with the fact that they are in their crude state and not as pure as the control antibiotic. The fact too that the extracts showed a broad spectrum of activity is significant in the drive to developing therapeutic substances against multidrug resistant organisms 
Table 5: Antimicrobial activity of seed extract at different concentrations

\begin{tabular}{|c|c|c|c|c|c|c|c|c|c|}
\hline \multirow[t]{3}{*}{ Isolates } & \multirow{3}{*}{$\begin{array}{l}\text { Ciprofloxa } \\
\text { cin } \\
\text { (Control) } \\
10 \mathrm{mg} / \mathrm{ml}\end{array}$} & \multicolumn{8}{|c|}{ Zones of Inhibition in mm at different concentrations (percentage of control) } \\
\hline & & \multicolumn{2}{|l|}{$30 \mathrm{mg} / \mathrm{ml}$} & \multicolumn{2}{|l|}{$20 \mathrm{mg} / \mathrm{ml}$} & \multicolumn{2}{|l|}{$10 \mathrm{mg} / \mathrm{ml}$} & \multicolumn{2}{|l|}{$5 \mathrm{mg} / \mathrm{ml}$} \\
\hline & & Aqueous & Ethanol & Aqueous & Ethanol & Aqueous & Ethanol & Aqueous & Ethanol \\
\hline S. aureus & 23.50 & $\begin{array}{l}20.5 \\
\pm 3.12 \\
(87 \%)\end{array}$ & $\begin{array}{l}24.1 \\
\pm 2.67 \\
(103 \%)\end{array}$ & $\begin{array}{l}15.8 \\
\pm 1.48 \\
(67 \%)\end{array}$ & $\begin{array}{l}18.13 \\
\pm 1.36 \\
(77 \%)\end{array}$ & $\begin{array}{l}13.5 \\
\pm 0.57 \\
(57 \%)\end{array}$ & $\begin{array}{l}14.9 \\
\pm 1.82 \\
(63 \%)\end{array}$ & $\begin{array}{l}5.73 \\
\pm 0.58 \\
(24 \%)\end{array}$ & $\begin{array}{l}10.1 \\
\pm 1.41 \\
(43 \%)\end{array}$ \\
\hline E. coli & 23.00 & $\begin{array}{l}16.05 \\
\pm 0.48 \\
(70 \%)\end{array}$ & $\begin{array}{l}23.8 \\
\pm 0.92 \\
(103 \%)\end{array}$ & $\begin{array}{l}14.8 \\
\pm 0.86 \\
(64 \%)\end{array}$ & $\begin{array}{l}18.07 \\
\pm 0.42 \\
(79 \%)\end{array}$ & $\begin{array}{l}12.7 \\
\pm 0.38 \\
(55 \%)\end{array}$ & $\begin{array}{l}14.3 \\
\pm 2.07 \\
(62 \%)\end{array}$ & $\begin{array}{l}3.73 \\
\pm 0.65 \\
(16 \%)\end{array}$ & $\begin{array}{l}5.57 \\
\pm 0.47 \\
(24 \%)\end{array}$ \\
\hline K. pneumonia & 25.50 & $\begin{array}{l}17.07 \\
\pm 0.99 \\
(67 \%)\end{array}$ & $\begin{array}{l}20.2 \\
\pm 0.92 \\
(79 \%)\end{array}$ & $\begin{array}{l}14.87 \\
\pm 0.65 \\
(58 \%)\end{array}$ & $\begin{array}{l}17.03 \\
\pm 0.93 \\
(67 \%)\end{array}$ & $\begin{array}{l}9.03 \\
\pm 0.93 \\
(35 \%)\end{array}$ & $\begin{array}{l}11.97 \\
\pm 0.65 \\
(47 \%)\end{array}$ & $\begin{array}{l}3.93 \\
\pm 0.42 \\
(15 \%)\end{array}$ & $\begin{array}{l}6.20 \\
\pm 0.46 \\
(24 \%)\end{array}$ \\
\hline S. typhi & 24.00 & $\begin{array}{l}16.7 \\
\pm 0.46 \\
(70 \%)\end{array}$ & $\begin{array}{l}24.47 \\
\pm 0.61 \\
(102 \%)\end{array}$ & $\begin{array}{l}14.77 \\
\pm 0.35 \\
(62 \%)\end{array}$ & $\begin{array}{l}19.23 \\
\pm 0.55 \\
(80 \%)\end{array}$ & $\begin{array}{l}13.43 \\
\pm 0.21 \\
(56 \%)\end{array}$ & $\begin{array}{l}15.06 \\
\pm 0.90 \\
(63 \%)\end{array}$ & $\begin{array}{l}4.87 \\
\pm 1.45 \\
(20 \%)\end{array}$ & $\begin{array}{l}7.07 \\
\pm 0.42 \\
(29 \%)\end{array}$ \\
\hline
\end{tabular}

Table 6: Minimum Inhibitory Concentration (MIC) and Minimum Bacterial Concentration (MBC) of Crude Extract in $\mathrm{mg} / \mathrm{ml}$

\begin{tabular}{|c|c|c|c|c|}
\hline \multirow{3}{*}{ Isolates } & \multicolumn{4}{|c|}{ Solvent } \\
\hline & \multicolumn{2}{|c|}{ Aqueous } & \multicolumn{2}{|c|}{ Ethanol } \\
\hline & $\mathrm{MIC}$ & $\mathrm{MBC}$ & MIC & $\mathrm{MBC}$ \\
\hline S. aureus & 2.5 & 3.0 & 3.0 & 3.5 \\
\hline E. coli & 3.0 & 3.0 & 3.5 & 3.5 \\
\hline K. pneumonia & 2.5 & 3.0 & 2.5 & 3.5 \\
\hline S. typhi & 3.0 & 3.5 & 3.0 & 4.0 \\
\hline
\end{tabular}

Minimum inhibitory concentration (MIC) and minimum bacterial concentration (MBC) values from the study are reported in table 6. MIC for aqueous extract ranged between 2.5 and $3.0 \mathrm{mg} / \mathrm{ml}$ while that of the ethanolic extract ranged between 2.5 and $3.5 \mathrm{mg} / \mathrm{ml}$. The MBC values obtained from the study was between 3.0 and $3.5 \mathrm{mg} / \mathrm{ml}$ for the aqueous extract and that for ethanolic extract between 3.5 and $4.0 \mathrm{mg} / \mathrm{ml}$. MIC and MBC values are normally used as predictive indices of the efficacy of antimicrobial agents. The figures obtained in this study are quite reasonable enough to warrant their possible pharmacological significance when compared to figures normally obtained for conventional antibiotics. El-Mahmood (2009)[15] observed that differences in their effectiveness could be due to the crude nature of plant extracts which may contain some impure substances that may be inert and do not have antibacterial activity. Unlike the synthetic antibiotics whose active ingredients are in their pure state.

\section{Conclusion}

Conclusively, it should be noted that although seed extracts of Monodora myristica contain some important bioactive components with pronounced antibacterial activities and also some important nutritional components, further studies need to be carried out on the plant seed in order to isolate, identify and characterize the active components so as to maximize the medicinal and nutritional potential of the plant seed.

\section{Acknowledgements}

The authors wish to thank Professor J.E. Ehiagbonare of the Department of Biological Sciences, Igbinedion University, Okada for authenticating the scientific name of the plant seed, Dr R.M. Mordi for making available to us the microbial isolates we used for the antimicrobial study from the University of Benin Teaching Hospital Laboratory and finally the Department of Basic Sciences, Faculty of Basic and Applied Sciences, Benson Idahosa University, Benin City for providing the laboratory space and enabling environment with which we did the research work.

\section{References}

[1]. M. Borget, Spices plants. In: R. Coste (ed.). The tropical Agriculturist, Macmillan, London, 1993, p 114

[2]. L.A. Shelef, Antimicrobial effects of spices. J. Food Safety. 1983, 6: 29-44.

[3]. L. L. Zaika, Spices and herbs: Their antimicrobial activity and its determination. J. Food Safety. 1988, 9: 97-118,

[4]. A. Sofowora, Medicinal plants and Traditional Medicine in Africa. Ibadan: Spectrum Books; 1993 p.150.

[5]. Okwu D.E. Evaluation of the chemical composition of indigenous Spices and flavouring agents. Global J. Pure Appl. Sci. 2001, 7(3): 455-459

[6]. N. Paster, M. Menasherov, U. Ravid, and B. Juven, Antifungal activity of oregano and tyme essential oils applied as fumigants against fungi attacking stored grain. J. Food Protect. 1995, 51:81-85.

[7]. M. A. Azzouz, and L.R. Bullerman, Comparative antimycotic effects of selected herbs and Spices, plant components and commercial antifungal, J. Food Protect. 1982, 45: 1248-1301. 
[8]. F. Sharififar, M.H. Moshafi, G. Dehghan- Nudehe, A. Ameri, F. Alishahi, and A. Pourhemati, Bioassay screening of the essential oil and various extracts from four spices medicinal plants. Pak. J. Pharm. Sci., 2009, 22(3): 317-322.

[9]. J. Giese, Spices and seasoning blends: A taste for all seasons. Food Technol. 1994, 48(4): 87-98

[10]. A. Sofowora, Medicinal plants and traditional medicine in Africa. (Spectrum Books, Ibadan), 1993, p.150

[11]. W. Burubai, A. J. Akor, A. H. Igoni, and Y. T. Uyate, Effects of temperature and moisture content on the strength properties of African Nutmeg (Monodora myristica). Bulg. J. Agric. Sci. 2007, 13: 703 - 712

[12]. K. O. Udeala, Preliminary evaluation of dike fat, a new tablet lubricant. J. Pharm. and Pharmacol., 2000, $32: 6$ - 9.

[13]. I. A. Owotokomo, and O. Ekundayo, Comparative study of the essential oils of Monodora myristica from Nigeria. Eur. Chem. Bull. 2012, 1(7): $263-265$.

[14]. U.E. Odoh, C. O. Ezugwu, and I. U. Ajali, Antimicrobial activity of Monodora myristica seed oil. J. Pharma. Allied Sci., 2004, 2: $233-236$.

[15]. M. A. El-Mahmood, Antibacterial activity of crude extracts of Euphorbia hirta against some bacteria associated with enteric infections. J. Med. Plants Res. 2009, 3 (7): 498-505.

[16]. M. Cheesbrough, District Laboratory Practice in Tropical Countries part 2. Low price editions. Cambridge University press, London. 2004, p 434.

[17]. S. T. Cowan and K. J. Steel, Manual for identification of bacteria, vol. 2. 3rd edn. (Cambridge University press, London, 2004).

[18]. S. A. Enabulele, and J. E. Ehiagbonare, Antimicrobial, Nutritional and Phytochemical properties of Perinari excelsa seeds. Int. J. Phar. and Bio Sci. 2011, 2(3): B459-B470.

[19]. A. S. Kamba, and L. G. Hassan, Phytochemical screening and antimicrobial activities of Euphobia balasamifera leaves stems and roots against some pathogenic microorganisms. Afr. J. Pharm. Sci. and Pharm. 2010, 1(1): 57-64.

[20]. AOAC. Association of Official Analytical Chemists, Official methods of Analysis, 14th edn. (Washington DC. 1984).

[21]. M. A. El-Mahmood, J. H. Doughari, and F. J. Chanji, In vitro antibacterial activities of crude extracts of Naucloa lantifolia and Daniella oliveri Sci. Res. Essay. 2008, 3(3): $102-105$.

[22]. O. J. Owolabi, E. Omogbai, and O. Obasuyi, Antifungal and antibacterial activities of the ethanolic and aqueous extracts of Kigelia africana (Bignoniaceae) stem bark. Afr. J. Biotechnol. 2007, 6(14): 1677-1680

[23]. M.M. Cowan, Plant products as antimicrobial agents. Clin. Microbiol. Rev. 1999, 12: 564-582.

[24]. R. Wills, B. McGlasson, D. Graham, and D. Joyce, Postharvest an introduction to the physiology and handling of fruit vegetables and ornamentals, 4th edn, (CAB International, 1998), pp. 15-32.

[25]. J. Koudou, A. W. Etou Ossibi, K. Aklikokou, A. A. Abena, M. Gbeassor and J. M. Bessiere, Chemical composition and hypotensive effects of essential oil of Monodora myristica. J. Biol. Sci. 2007, 7(6): 937 - 942.

[26]. O. O. Ayelaagbe, E. O. Ajaiyeoba, and O. Ekundayo, studies on the seed oil of Parkia biglobosa and Parkia bicolor. J. Plant foods Hum. Nutr. 1996, 49: 229-233.

[27]. R. S. Goodhart, and M. E. Shils, Modern Nutrition in Health and Diseases. 6th edn. Lea and Febiger, Philadelphia, U.S.A. 1980, pp. $150-325$.

[28]. P. C. Champe, and R. A. Harvey, Lippincott's illustrated reviews: Biochemistry, 2nd edn. (Lippincott Raven Publishers Philadelphia, U.S.A. 1994), pp. 303-340

[29]. E. G. D. Eyabi, Understanding the product and the process. In: P. Fellows and B. Axtell (ed), A Handbook for setting up and running a small food business. Opportunities in food processing series. (Washington: ACP-EU Technical Centre for Agricultural and Rural Cooperation (CTA), 2001), pp. 29-50.

[30]. D. Karou, A. Savadogo, A. Canini, S. Yamoogo, C. Moniesano, J. Simpore, V. Golizi, and A. S. Traore, Antibacterial activity of alkaloids from Cida acuta. Afr. J. Biotechnol. 2006, 5(2): 195-200

[31]. J. N. Ellof, Which extractan should be used for screening and isolation of antimicrobial components from plants? J. Ethnopharm. 1998, 60: 1-8.

[32]. A. A. Adegoke, and B. C. Adebayo-tayo, Antibacterial activity and phytochemical analysis of leaf extracts of Lasiethera africanum. Afr. J. Biotechnol. 2009, 8(1): 077-080.

[33]. S. L. Kela, and J. H. Kufeji, Screening of some Nigerian Plants for bactericidal activity. J. Microbiol. 1995, 10: 18-22 